\title{
Influence of Pulmonary Rehabilitation on Lung Function Changes After the Lung Resection for Primary Lung Cancer in Patients with Chronic Obstructive Pulmonary Disease
}

\author{
Natasa Mujovic ${ }^{1,2, *}$, Nebojsa Mujovic ${ }^{2,3}$, Dragan Subotic ${ }^{2,4}$, Maja Ercegovac ${ }^{2,4}$, Andjela \\ Milovanovic $^{1,2}$, Ljubica Nikcevic ${ }^{5}$, Vladimir Zugic ${ }^{2,6}$, Dejan Nikolic ${ }^{2,7}$ \\ ${ }^{1}$ Clinic for Physical Medicine and Rehabilitation, Clinical Center of Serbia, Belgrade, Serbia \\ ${ }^{2}$ Faculty of Medicine, University of Belgrade, Belgrade, Serbia \\ ${ }^{3}$ Clinic for Cardiology, Clinical Center of Serbia, Belgrade, Serbia \\ ${ }^{4}$ Clinic for Thoracic Surgery, Clinical Center of Serbia, Belgrade, Serbia \\ ${ }^{5}$ Special Hospital for Cerebrovascular Disorders "Saint Sava“, Belgrade, Serbia \\ ${ }^{6}$ Clinic for Pulmonary disease and TB, Clinical Center of Serbia, Belgrade, Serbia \\ ${ }^{7}$ Department of Physical Medicine and Rehabilitation, University Children's Hospital, Belgrade, Serbia
}

[Received January 29, 2015; Revised May 2, 2015; Accepted May 3, 2015]

\begin{abstract}
Influence of physiotherapy on the outcome of the lung resection is still controversial. Study aim was to assess the influence of physiotherapy program on postoperative lung function and effort tolerance in lung cancer patients with chronic obstructive pulmonary disease (COPD) that are undergoing lobectomy or pneumonectomy. The prospective study included 56 COPD patients who underwent lung resection for primary non small-cell lung cancer after previous physiotherapy (Group A) and 47 COPD patients (Group B) without physiotherapy before lung cancer surgery. In Group A, lung function and effort tolerance on admission were compared with the same parameters after preoperative physiotherapy. Both groups were compared in relation to lung function, effort tolerance and symptoms change after resection. In patients with tumors requiring a lobectomy, after preoperative physiotherapy, a highly significant increase in $\mathrm{FEV}_{1}, \mathrm{VC}, \mathrm{FEF}_{50}$ and $\mathrm{FEF}_{25}$ of $20 \%, 17 \%, 18 \%$ and $16 \%$ respectively was registered with respect to baseline values. After physiotherapy, a significant improvement in 6-minute walking distance was achieved. After lung resection, the significant loss of $\mathrm{FEV}_{1}$ and $\mathrm{VC}$ occurred, together with significant worsening of the small airways function, effort tolerance and symptomatic status. After the surgery, a clear tendency existed towards smaller FEV 1 loss in patients with moderate to severe, when compared to patients with mild baseline lung function impairment. A better FEV 1 improvement was associated with more significant loss in FEV 1 . Physiotherapy represents an important part of preoperative and postoperative treatment in COPD patients undergoing a lung resection for primary lung cancer.
\end{abstract}

Key words: pulmonary rehabilitation, preoperative physiotherapy, lung cancer, lobectomy, pneumonectomy

During the previous decade, functional assessment of patients that were diagnosed with lung cancer that are undergoing surgery significantly changed. Cut-off values of ventilatory parameters that are used in treatment planning particularly forthe safe resection have been changed, along with improvement of postoperative lung function prediction and operative risk assessment methods [1-3]. In addition, as it was convincingly demonstrated that age itself is not a contraindication for surgery, there is increasing evidence of safe surgical treatment in septuagenarians and even in octogenarians $[4,5]$. 
Selection criteria are currently based not only on respiratory function tests, but also on measurement of the oxygen consumption in effort and diffusion across the alveolocapillary membrane. In fact, recent data indicate that the prediction of postoperative $\mathrm{DL}_{\mathrm{CO}}$ might more reliably predict postoperative complications and mortality, than usual prediction of postoperative $\mathrm{FEV}_{1}[6]$. As physiotherapy is currently routinely used in most surgical candidates, irrespectively of their fitness for surgery, it is difficult to separately analyze the specific contribution of this treatment modality to the outcome of surgery.

In our previous study, we have demonstrated beneficial effects of respiratory rehabilitation for patients with chronic obstructive pulmonary disease (COPD) and non-small cell lung cancer [7]. Therefore, the aim of the study is to assess the influence of physiotherapy program on postoperative lung function and effort tolerance in lung cancer patients with chronic obstructive pulmonary disease (COPD) that are undergoing lobectomy or pneumonectomy. Comparisons of preoperative respiratory function and effort tolerance tests before and after physiotherapy program with the same tests performed postoperatively will be applied. These findings will be further compared with a group of COPD patients without preoperative physiotherapy.

\section{MATERIALS AND METHODS}

The main objective of our study was to determine whether the implementation of preoperative physiotherapy has any influence on lung function and incidence of pulmonary complications after lung resection surgery. We were also interested in finding out the effects of preoperative physiotherapy on preoperative and postoperative performance status of our patients.

Table 1. Baseline patients characteristics

\begin{tabular}{|c|c|c|c|}
\hline & Group A $(n=56)$ & Group B (n=47) & $\mathrm{p}$ \\
\hline Age (years) MV \pm SD & $62 \pm 7$ & $59 \pm 9$ & 0.134 \\
\hline Male gender N (\%) & $49(88)$ & $41(87)$ & 0.968 \\
\hline Smoking history N (\%) & $50(89)$ & $44(94)$ & 0.438 \\
\hline Co-morbidities N (\%) & $50(89)$ & $34(72)$ & 0.027 \\
\hline Hypertension N (\%) & $28(50)$ & $18(38)$ & 0.234 \\
\hline Coronary disease N (\%) & $11(20)$ & $9(19)$ & 0.950 \\
\hline Heart failure $\mathrm{N}(\%)$ & $4(7)$ & $1(2)$ & 0.238 \\
\hline Diabetes mellitus N (\%) & $7(13)$ & $4(8)$ & 0.514 \\
\hline Chronic renal failure $\mathrm{N}(\%)$ & $0(0)$ & $2(4)$ & 0.119 \\
\hline COPD stage: I/II/III/IV N (\%) & $10(18) / 39(69) / 6(11) / 1(2)$ & $24(51) / 22(47) / 1(2) / 0(0)$ & 0.002 \\
\hline \multicolumn{4}{|l|}{ Basal spirometry: } \\
\hline $\mathrm{FEV}_{1}(\mathrm{~mL}) \mathrm{MV} \pm \mathrm{SD}$ & $1948 \pm 569$ & $2509 \pm 741$ & $<0.001$ \\
\hline $\mathrm{FEV}_{1} \%$ pred. $\mathrm{MV} \pm \mathrm{SD}$ & $65 \pm 14$ & $79 \pm 18$ & $<0.001$ \\
\hline $\mathrm{VC}(\mathrm{mL}) \mathrm{MV} \pm \mathrm{SD}$ & $3352 \pm 873$ & $3731 \pm 1088$ & 0.055 \\
\hline $\mathrm{VC} \%$ pred. $\mathrm{MV} \pm \mathrm{SD}$ & $88 \pm 15$ & $94 \pm 21$ & 0.116 \\
\hline Tiffneau index $\% \mathrm{MV} \pm \mathrm{SD}$ & $56 \pm 8$ & $62 \pm 6$ & $<0.001$ \\
\hline $\mathrm{FEF}_{50} \% \mathrm{MV} \pm \mathrm{SD}$ & $29 \pm 14$ & $44 \pm 24$ & $<0.001$ \\
\hline $\mathrm{IC} \% \mathrm{MV} \pm \mathrm{SD}$ & $74 \pm 11$ & $84 \pm 12$ & $<0.01$ \\
\hline $\mathrm{FEF}_{25} \% \mathrm{MV} \pm \mathrm{SD}$ & $27 \pm 18$ & $42 \pm 24$ & 0.001 \\
\hline \multicolumn{4}{|l|}{ Pulmonary resection: } \\
\hline Pneumonectomy N (\%) & $13(23)$ & $5(11)$ & 0.094 \\
\hline Lobectomy N (\%) & $43(77)$ & $42(89)$ & 0.094 \\
\hline Total hospital stay (days) MV $\pm \mathrm{SD}$ & $36 \pm 19$ & $25 \pm 12$ & $<0.001$ \\
\hline Preop.hospital stay (days) MV \pm SD & $21 \pm 12$ & $9 \pm 6$ & $<0.001$ \\
\hline Postop.hospital stay (days) MV \pm SD & $16 \pm 9$ & $16 \pm 8$ & 0.571 \\
\hline Total complications $\mathbf{N}(\%)$ & $20(36)$ & $21(45)$ & 0.354 \\
\hline Pulmonary complications N (\%) & 17(30) & $20(43)$ & 0.199 \\
\hline In-hospital mortality N (\%) & $2(4)$ & $0(0)$ & 0.191 \\
\hline
\end{tabular}

$\mathrm{COPD}=$ chronic obstructive pulmonary disease. 
The study included103 patients that were diagnosed with COPD and surgically treated for primary non-small cell lung carcinoma (NSCLC). The group was divided according to the implementation of physiotherapy program into two subgroups: Group A was consisted of 56 patients with COPD which were included into preoperative physiotherapy. The Group B included 47 patients with COPD in whom preoperative physiotherapy was not performed. The patients were consecutively assigned to the main and control group. Prior inclusion into the study patients were informed about study protocol and consent was obtained. The study followed the principles of good clinical practice and Helsinki declaration.

\section{Patient characteristics}

In the Group A, there were $49(88 \%)$ males with ratio $\mathrm{M}: \mathrm{F}=7: 1$. The mean age of patients was $62 \pm 7$ years. There were 50(89\%) current smokers.

Based on spirometry on admission, grading of the COPD severity was done according to GOLD criteria and patients were classified into stages I-IV [8]. Most patients 39 (70\%) had moderate COPD (category II), while severe (category III and IV) and mild (category I) COPD existed in $7(13 \%)$ and $10(18 \%)$ patients, respectively.

Lobectomy and pneumonectomy were done in 43 (77\%) and $13(23 \%)$ patients, respectively.

Patient characteristics for both subgroups are presented in table 1.

Table 2. Changes of the lung function, effort tolerance and symptomatic status in patients of the Group Awith lobectomy

\begin{tabular}{|c|c|c|c|c|c|c|c|c|c|}
\hline \multirow[t]{2}{*}{$n=43$} & \multirow{2}{*}{$\begin{array}{l}\text { Before } \\
\text { Pre-PR } \\
\text { (T1) }\end{array}$} & \multirow{2}{*}{$\begin{array}{l}\text { after } \\
\text { Pre-PR } \\
\text { (T2) }\end{array}$} & \multirow{2}{*}{$\begin{array}{l}\text { after } \\
\text { resection } \\
\text { (T3) }\end{array}$} & \multicolumn{2}{|l|}{$\Delta[\mathrm{T} 2-\mathrm{T} 1]$} & \multicolumn{2}{|l|}{$\Delta$ [T2-T3] } & \multicolumn{2}{|c|}{$\Delta$ [T1-T3] } \\
\hline & & & & $\begin{array}{l}\text { mean } \\
{[95 \% \mathrm{CI}]}\end{array}$ & $\begin{array}{l}\text { mean } \\
\text { change }\end{array}$ & $\begin{array}{l}\text { mean } \\
{[95 \%} \\
\text { CI] }\end{array}$ & $\begin{array}{l}\text { mean } \\
\text { change }\end{array}$ & $\begin{array}{l}\text { mean } \\
{[95 \%} \\
\mathrm{CI}]\end{array}$ & $\begin{array}{l}\text { mean } \\
\text { change }\end{array}$ \\
\hline $\mathrm{FEV}_{1}(\mathrm{ml})$ & $1985 \pm 544$ & $2334 \pm 620$ & $1795 \pm 544$ & $\begin{array}{l}346^{* *} \\
{[259,} \\
434]\end{array}$ & $20 \%$ & $\begin{array}{l}566 * * \\
{[470,} \\
661]\end{array}$ & $23 \%$ & $\begin{array}{l}189 * \\
{[77,} \\
300]\end{array}$ & $7 \%$ \\
\hline $\begin{array}{l}\text { FEV } 1 \% \\
\text { pred. }\end{array}$ & $64 \pm 14$ & $76 \pm 15$ & $58 \pm 13$ & $\begin{array}{l}11 * * \\
{[9,13]}\end{array}$ & $20 \%$ & $\begin{array}{l}19 * * \\
{[15,22]}\end{array}$ & $23 \%$ & $\begin{array}{l}6^{* *} \\
{[3,10]}\end{array}$ & $7 \%$ \\
\hline VC (ml) & $3394 \pm 841$ & $3877 \pm 878$ & $3068 \pm 858$ & $\begin{array}{l}469 * * \\
{[369,} \\
569]\end{array}$ & $17 \%$ & $\begin{array}{l}763 * * \\
{[590,} \\
935]\end{array}$ & $20 \%$ & $\begin{array}{l}284 * \\
{[93,} \\
475]\end{array}$ & $6 \%$ \\
\hline $\begin{array}{ll}\text { VC } & \% \\
\text { pred. } & \end{array}$ & $89 \pm 16$ & $103 \pm 16$ & $81 \pm 15$ & $\begin{array}{l}13 * * \\
{[11,16]}\end{array}$ & $18 \%$ & $\begin{array}{l}22 * * \\
{[18,26]}\end{array}$ & $21 \%$ & $\begin{array}{l}8^{* *} \\
{[3,12]}\end{array}$ & $6 \%$ \\
\hline $\begin{array}{l}\text { Tiffeneau } \\
\text { index }(\%)\end{array}$ & $55 \pm 9$ & $59 \pm 9$ & $55 \pm 10$ & $\begin{array}{l}3 * * \\
{[1,5]}\end{array}$ & $7 \%$ & $\begin{array}{l}5^{* *} \\
{[2,7]}\end{array}$ & $7 \%$ & $\begin{array}{l}1^{*} \\
{[-2,4]}\end{array}$ & $1 \%$ \\
\hline IC (\%) & $75 \pm 11$ & $84 \pm 7$ & $77 \pm 9$ & $-*$ & $9 \%$ & $-*$ & $7 \%$ & - & $2 \%$ \\
\hline $\mathrm{FEF}_{50}(\%)$ & $30 \pm 15$ & $34 \pm 14$ & $19 \pm 11$ & $\begin{array}{l}3^{* *} \\
{[1,6]}\end{array}$ & $18 \%$ & $\begin{array}{l}12 * * \\
{[8,16]}\end{array}$ & $39 \%$ & $\begin{array}{l}10^{* * *} \\
{[5,14]}\end{array}$ & $29 \%$ \\
\hline $\mathrm{FEF}_{25}(\%)$ & $30 \pm 16$ & $32 \pm 16$ & $19 \pm 12$ & $\begin{array}{l}2^{*} \\
{[-1,5]}\end{array}$ & $16 \%$ & $\begin{array}{l}11 * * \\
{[7,16]}\end{array}$ & $36 \%$ & $\begin{array}{l}11^{* *} \\
{[5,16]}\end{array}$ & $25 \%$ \\
\hline 6MWD (m) & $375 \pm 99$ & $428 \pm 91$ & $349 \pm 91$ & $\begin{array}{l}53 * * \\
{[42,64]}\end{array}$ & $16 \%$ & $\begin{array}{l}85^{* *} \\
{[71,100]}\end{array}$ & $19 \%$ & $\begin{array}{l}31^{* *} \\
{[18,44]}\end{array}$ & $6 \%$ \\
\hline $\begin{array}{l}\text { Dyspnea } \\
\text { before } \\
6 \mathrm{MWT}\end{array}$ & $2.2 \pm 0.9$ & $1.2 \pm 0.8$ & $2.0 \pm 0.6$ & $\begin{array}{l}-1.0^{* *} \\
{[-0.8,} \\
1.2]\end{array}$ & - & $\begin{array}{l}-0.8 * * \\
{[-0.5, \quad-} \\
1.1]\end{array}$ & - & $\begin{array}{l}0.2 \\
{[-0.2,} \\
0.6]\end{array}$ & - \\
\hline $\begin{array}{l}\text { Dyspnea } \\
\text { after } \\
6 \mathrm{MWT}\end{array}$ & $3.2 \pm 0.9$ & $2.1 \pm 0.8$ & $2.9 \pm 0.7$ & $\begin{array}{l}-1.1 * * \\
{[-0.9, \quad-} \\
1.3]\end{array}$ & - & $\begin{array}{l}-1.0 * * \\
{[-0.7, \quad-} \\
1.3]\end{array}$ & - & $\begin{array}{l}0.2 \\
{[-0.2,} \\
0.6]\end{array}$ & - \\
\hline
\end{tabular}




\section{Spirometry}

Spirometry was performed on Lilly pneumotachometer (Master Screen Pneumo, Viasys Helathcare, Germany). All measurements were performed according to ATS/ERS standards [9]. For interpretation of spirometry data we used European Respiratory Society/ European Community for Steel and Coal predicted values [10].

\section{Preoperative work up}

For the entire study group, a usual work up was performed aimed at assessment of the local and distal spread of malignant disease according to actual recommendations [11].

Every patients was performed a standard spirometry on the day of operation.

All patients underwent a 6MWT, according to American Thoracic Society guidelines [12]. The test was performed in the 54 meter long department hall, while walking in a straight line between two markers, without changing the walking speed.

Assessment of the degree of dyspnea was done according to modified 10-degree Borg scale [13]. Patients were requested to assess their dyspnea according to the aforementioned scale at rest before and immediately after completion of the 6MWT.

Patients from the Group A were included in the program of preoperative therapy according to institutional protocol. It consisted of (1) intravenous bronchodilators (Theophylline derivatives $12.5 \mathrm{mg}$ or $25 \mathrm{mg}$ twice a day, without corticosteroids; (2) pulmonary physiotherapy and (3) general physiotherapy. Pulmonary physiotherapy was performed 5 days a week for 2-4 weeks, in form of 3 daily 45 minutes sessions. It consisted of bronchodilator aerosols (Salbutamol) in concentration of $0.5 \mathrm{ml} / 3 \mathrm{ml}$ in $0.9 \% \mathrm{NaCl}$ solution, administered during 10 minutes through "Dräger" jet nebulizers, under $5 \mathrm{kPa}$ pressure from the centralized oxygen system. During the period of aerosol delivery, patients were performing a technique of diaphragmatic breathing, after previous education and under the educated and licensed therapist's surveillance. In addition to this, all patients underwent exercises for the thoracic cage expansion and shoulder mobilization that were performed in front of the mirror, with 10 repetitions within a single series, again under physiotherapist's control. During the second week, this set of exercises was performed under $1 \mathrm{~kg}$ loading form of elastic bands in two series, each with 10 repetitions. Finally, preoperative work up included also patient education and making patients familiar with exercise sets that will be used in the early postoperative period.
After completion of this round of physiotherapy, control spirometry, 6MWT and symptom assessment were repeated in the same way as on admission.

Patients from group B received intravenous bronchodilators (Theophylline derivatives $12.5 \mathrm{mg}$ or $25 \mathrm{mg}$ twice a day), as well as bronchodilator aerosols (Salbutamol) in concentration of $0.5 \mathrm{ml} / 3 \mathrm{ml}$ in $0.9 \% \mathrm{NaCl}$ solution, administered during 10 minutes through "Dräger" jet nebulizers, under $5 \mathrm{kPa}$ pressure from the centralized oxygen system and without physiotherapy.

\section{Postoperative work-up}

An exercise comprising diaphragmatic (abdominal) breathing was followed by those for peripheral circulation, thoracic cage expansion and shoulder mobilization, with the addition of aerosolized bronchodilators. During the first postoperative day, this set of exercises was performed at the bed level with $75 \%$ elevation of the back. On the second postoperative day, the same set of exercises was performed with a patient sitting at the edge of the bed, with the addition of walking through the room with the therapist from the third postoperative day and later. The same regimen was repeated 3-4 times a day during the entire stay in the ICU. After discharge from the ICU, postoperative physiotherapy was performed twice a day.

During the first outpatient control within one month after discharge from hospital, all patients underwent spirometry, 6MWT and symptom assessment, as previously described.

\section{Statistical analysis}

Descriptive statistics are presented as mean values (MV) and standard deviation (SD) $\mathrm{MV} \pm \mathrm{SD}$ or mean with $95 \%$ confidence interval (CI) for continuous variables, and numbers with percentages for categorical variables. Normal distribution of all continuous variables was tested using the Shapiro-Wilk test and for the intergroup comparison, the unpaired t-test or Mann-Whitney-U test was used. In case of normally distributed variables, comparisons between different time points (baseline values, after preoperative physiotherapy and after surgery) were performed by one way repeated measures ANOVA followed by the Bonferroni test. Otherwise, Friedman test was used with post hoc analysis by the Wilcoxon signed rank test (with Holm-Bonferroni correction for significance level).

Changes of lung function between subgroups of patients with different COPD stages were tested by using the Kruskal-Wallis test with post hoc Mann-Whitney U test. 
A

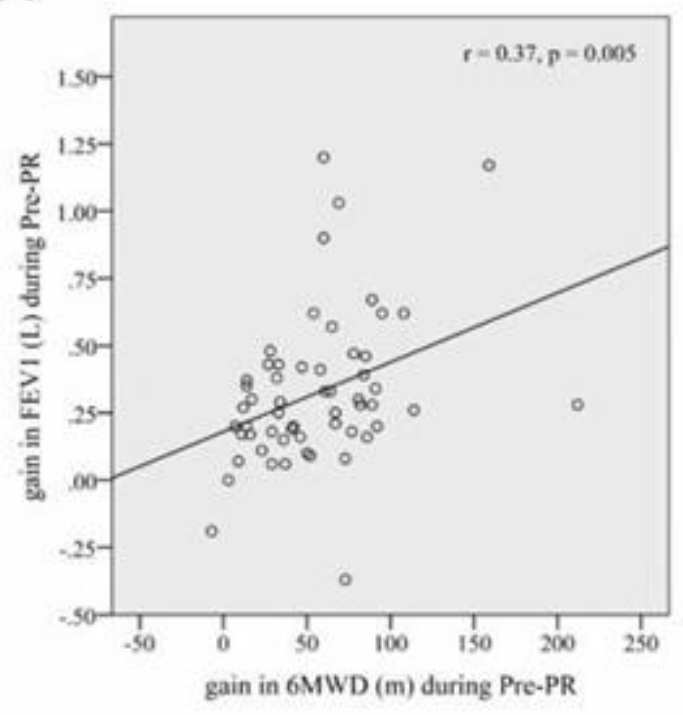

B

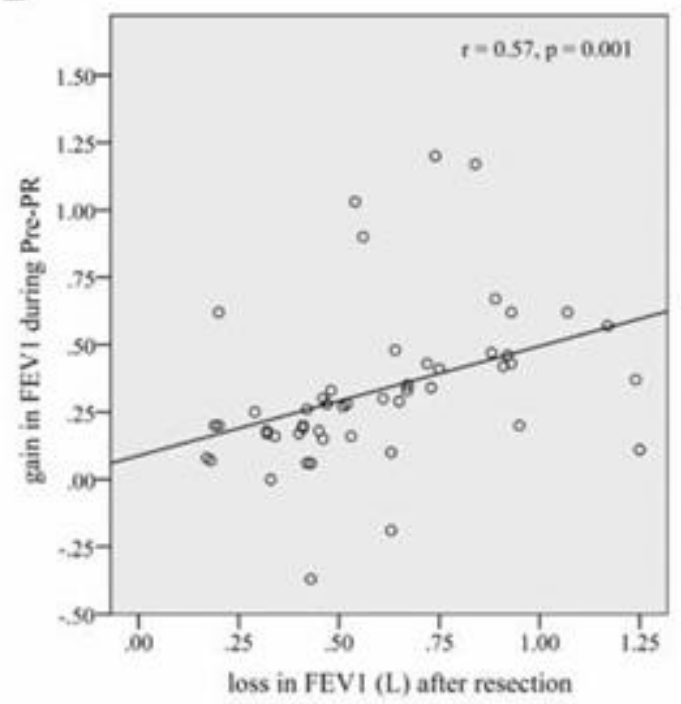

Figure 1. Changes in FEV $_{1}$ parameter. (A) Correlation between the gain in $\mathrm{FEV}_{1}$ and prolongation of the 6MWD during the preoperative physiotherapy. (B) Inverse correlation between the amplitude of $\mathrm{FEV}_{1}$ improvement after preoperative physiotherapy and postoperative loss in $\mathrm{FEV}_{1} . \mathrm{FEV}_{1}=$ forced expiratory volume in the first second, in liters; $6 \mathrm{MWD}=$ six minute walking distance, in meters; Pre-PR=preoperative pulmonary rehabilitation.

For the determination of correlation between variables, Pearson correlation test (normal distribution) or Spearman rank correlation test (asymmetrical distribution) was used.

A two tailed $p<0.05$ was considered statistically significant. Data were analyzed with the use of SPSS for Windows, version 17.0.

\section{RESULTS}

\section{Changes in lung function after preoperative physiotherapy}

A statistically significant improvement of ventilatory parameters was registered in patients whose local extent of the tumor required a lobectomy during the preoperative treatment: mean increase in $\mathrm{FEV}_{1}, \mathrm{VC}, \mathrm{IC}, \mathrm{FEF}_{50}$ and $\mathrm{FEF}_{25}$ of $20 \%, 17 \%, 9 \%, 18 \%$ and $16 \%$, respectively, in comparison to baseline values (Table 2).

In group of patients whose local tumor spread required a pneumonectomy, preoperative physiotherapy led to statistically significant improvement in $\mathrm{FEV}_{1} \%$, and IC\% while the evident improvement of other analyzed parameters did not reach a level of statistical significance (Table 3).

\section{Changes in effort tolerance and symptomatic status after preoperative physiotherapy}

After preoperative physiotherapy program, a significant improvement in 6MWD was achieved, with an average gain of $53 \mathrm{~m}(16 \%, \mathrm{p}<0.001)$ and $55 \mathrm{~m}(21 \%, \mathrm{p}<0.002)$, respectively, in candidates for lobectomy and pneumonectomy. A positive correlation was found between the gain in $\mathrm{FEV}_{1}$ and prolongation of the 6MWDduring the preoperative treatment $(\mathrm{r}=0.37$, $\mathrm{p}=0.005$ ), (Fig. 1A).A symptom relief after preoperative physiotherapy followed the same trend both in candidates for lobectomy (Table 2) and pneumonectomy (Table 3). Dyspnea was less severe both before and after the 6MWT in candidates for both types of resection.

\section{Influence of the lung resection on postoperative lung function}

After both types of resection, the significant loss of $\mathrm{FEV}_{1}$, $\mathrm{VC}$ and IC occurred, together with significant worsening of the small airways function (Table 2 and Table 3). Although differences between postoperative and preoperative values of all ventilatory parameters, except for IC\% were significant regardless of whether postoperative values were compared to those obtained 
with or without preoperative physiotherapy, in patients with lobectomy, these differences were evidently lower when the comparison was made in relation to values before physiotherapy (loss in $\mathrm{FEV}_{1:} 23 \%$ vs.7\%, loss in VC: $20 \%$ vs. $6 \%$ ). In patients with pneumonectomy, these differences were minimal (38\% vs. $29 \%$ for $\mathrm{FEV}_{1}, 39 \%$ vs. $33 \%$ for VC). We didn't find significant differences between mean values of IC\% before physiotherapy and after lung resection whether it was lobectomy or pneumonectomy.

In six patients, an improvement in $\mathrm{FEV}_{1}$ (mean 22\%, 95\% CI: $10 \%$ to $35 \%$ ) and in $\mathrm{FEF}_{50}$ (mean $60 \%$, 95\% CI: $4 \%$ to $116 \%$ ) was registered, but only if postoperative values were compared with those measured before physiotherapy program.
Comparison between the Group A and Group B in relation to lung function changes after the lung resection, is presented in Fig. 2A-C. Although the preoperative $\mathrm{FEV}_{1}$ and VC were significantly lower in the Group A, both parameters reached similar values after performed physiotherapy. No significant difference existed between the groups in relation to the postoperative loss either in $\mathrm{FEV}_{1}$ (Fig. 2A) or VC (Fig. 2B). Although the postoperative loss in the small airways function (Fig. 2C) followed the similar trend in both groups, the small airways function in the Group B was evidently better postoperatively.

Table 3. Changes of the lung function, effort tolerance and symptomatic status in patients of the Group A with pneumonectomy

\begin{tabular}{|c|c|c|c|c|c|c|c|c|c|}
\hline \multirow[t]{2}{*}{$n=13$} & \multirow{2}{*}{$\begin{array}{c}\text { before } \\
\text { Pre-PR } \\
\text { (T1) }\end{array}$} & \multirow{2}{*}{$\begin{array}{c}\text { after } \\
\text { Pre-PR } \\
\text { (T2) }\end{array}$} & \multirow{2}{*}{$\begin{array}{c}\text { after } \\
\text { resection } \\
\text { (T3) }\end{array}$} & \multicolumn{2}{|c|}{$\Delta[\mathrm{T} 2-\mathrm{T} 1]$} & \multicolumn{2}{|c|}{$\Delta$ [T2-T3] } & \multicolumn{2}{|c|}{$\Delta$ [T1-T3] } \\
\hline & & & & $\begin{array}{l}\text { mean } \\
{[95 \%} \\
\mathrm{CI}]\end{array}$ & $\%$ change & $\begin{array}{l}\text { mean } \\
{[95 \% \mathrm{CI}]}\end{array}$ & $\%$ change & $\begin{array}{l}\text { mean } \\
{[95 \% \mathrm{CI}]}\end{array}$ & $\begin{array}{l}\% \\
\text { change }\end{array}$ \\
\hline FEV1 (ml) & $1888 \pm 625$ & $2127 \pm 501$ & $1344 \pm 392$ & $\begin{array}{c}236 \\
{[45,426]}\end{array}$ & 17 & $\begin{array}{c}824 * * \\
{[640,1009]}\end{array}$ & 38 & $\begin{array}{c}576 * * \\
{[390,763]}\end{array}$ & 29 \\
\hline $\begin{array}{l}\text { FEV }_{1} \quad \% \\
\text { pred. }\end{array}$ & $65 \pm 12$ & $74 \pm 12$ & $48 \pm 6$ & $\begin{array}{c}9^{*} \\
{[3,16]}\end{array}$ & 16 & $\begin{array}{c}28 * * \\
{[22,35]}\end{array}$ & 36 & $\begin{array}{c}18 * * \\
{[13,24]}\end{array}$ & 27 \\
\hline $\mathrm{VC}(\mathrm{ml})$ & $3216 \pm 927$ & $3565 \pm 831$ & $2187 \pm 672$ & $\begin{array}{c}296 \\
{[17,574]}\end{array}$ & 13 & $\begin{array}{c}1385 * * \\
{[1071} \\
1700]\end{array}$ & 39 & $\begin{array}{c}1105 * * \\
{[820} \\
1391]\end{array}$ & 33 \\
\hline VC \% pred. & $89 \pm 16$ & $99 \pm 18$ & $62 \pm 10$ & $\begin{array}{c}10 \\
{[1,18]}\end{array}$ & 13 & $\begin{array}{c}38 * * \\
{[29,47]}\end{array}$ & 37 & $\begin{array}{c}29 * * \\
{[23,35]}\end{array}$ & 31 \\
\hline $\begin{array}{l}\text { Tiffeneau } \\
\text { index }(\%)\end{array}$ & $58 \pm 6$ & $60 \pm 8$ & $57 \pm 12$ & $\begin{array}{c}3 \\
{[0,7]}\end{array}$ & 4 & $\begin{array}{c}4 \\
{[-2,10]}\end{array}$ & 7 & $\begin{array}{c}0 \\
{[-8,7]}\end{array}$ & 1 \\
\hline IC (\%) & $73 \pm 13$ & $82 \pm 14$ & $70 \pm 11$ & $-*$ & 9 & $-* *$ & 12 & - & 3 \\
\hline $\operatorname{FEF}_{50}(\%)$ & $30 \pm 10$ & $33 \pm 8$ & $18 \pm 11$ & $\begin{array}{c}3 \\
{[-1,7]}\end{array}$ & 15 & $\begin{array}{c}15^{* *} \\
{[6,24]}\end{array}$ & 44 & $\begin{array}{c}12 * \\
{[1,23]}\end{array}$ & 32 \\
\hline $\mathrm{FEF}_{25}(\%)$ & $31 \pm 9$ & $32 \pm 11$ & $17 \pm 11$ & $\begin{array}{c}1 \\
{[-6,9]}\end{array}$ & 12 & $\begin{array}{c}15^{*} \\
{[5,26]}\end{array}$ & 38 & $\begin{array}{c}13^{*} \\
{[3,23]}\end{array}$ & 39 \\
\hline 6MWD (m) & $354 \pm 78$ & $422 \pm 82$ & $327 \pm 74$ & $\begin{array}{c}55^{* *} \\
{[34,76]}\end{array}$ & 21 & $\begin{array}{c}87 * * \\
{[66,108]}\end{array}$ & 23 & $\begin{array}{c}31 * * \\
{[16,46]}\end{array}$ & 8 \\
\hline $\begin{array}{l}\text { Dyspnea } \\
\text { before } \\
6 \mathrm{MWT}\end{array}$ & $2.5 \pm 0.9$ & $1.4 \pm 0.9$ & $2.1 \pm 0.5$ & $\begin{array}{c}-1.0 * * \\
{[-0.7,-} \\
1.3]\end{array}$ & - & $\begin{array}{c}-0.9 * \\
{[-0.3,-1.5]}\end{array}$ & - & $\begin{array}{c}0 \\
{[-0.7,0.7]}\end{array}$ & - \\
\hline $\begin{array}{l}\text { Dyspnea } \\
\text { after } 6 \mathrm{MWT}\end{array}$ & $3.5 \pm 0.9$ & $2.4 \pm 0.6$ & $3.3 \pm 0.6$ & $\begin{array}{c}-1.0 * * \\
{[-0.7,-} \\
1.3]\end{array}$ & - & $\begin{array}{c}-1.0 * * \\
{[-0.5,-1.5]}\end{array}$ & - & $\begin{array}{c}0 \\
{[-0.7,0.7]}\end{array}$ & - \\
\hline
\end{tabular}

Pre-PR=preoperative pulmonary rehabilitation; $\Delta=$ difference between two measured values; $\mathrm{FEV}_{1}=$ forced expiratory volume in the first second; $\mathrm{VC}=$ vital capacity; IC=inspiratory capacity; FEF=forced expiratory flow; $6 \mathrm{MWD}=$ six minute walking distance; $6 \mathrm{MWT}=$ six minute walking test; $\mathrm{T} 1=$ values before preoperative physiotherapy; $\mathrm{T} 2=$ values after preoperative physiotherapy; $\mathrm{T} 3=$ values after lung resection; ${ }^{*} \mathrm{p}<0.05 ; *{ }^{*} \mathrm{p}<0.01$ 
A

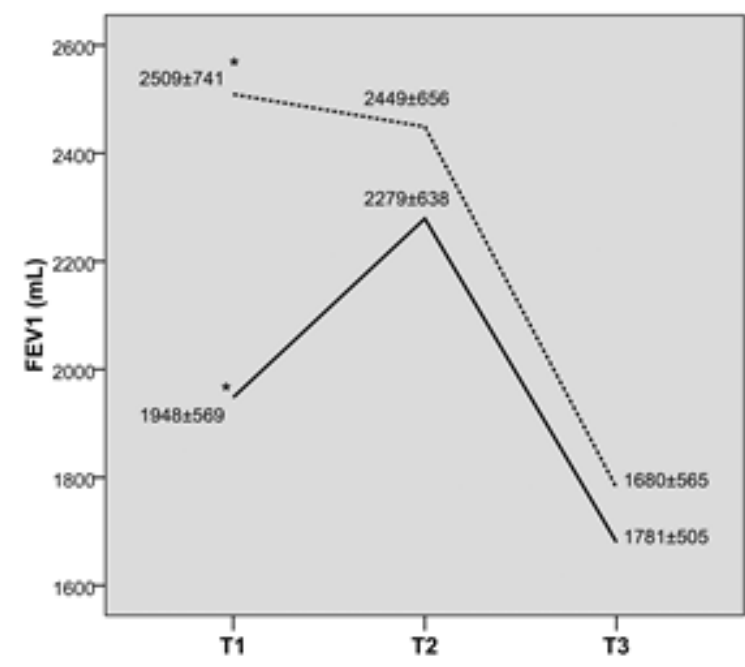

C

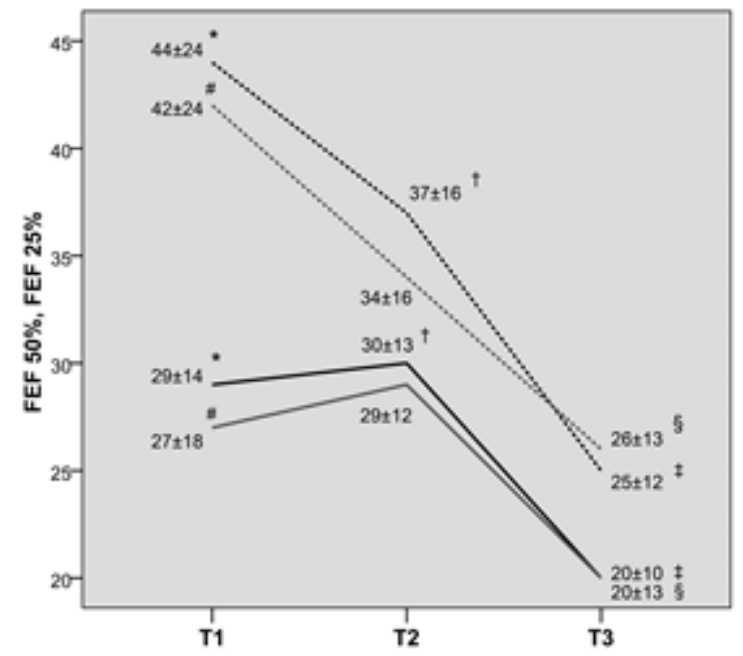

B

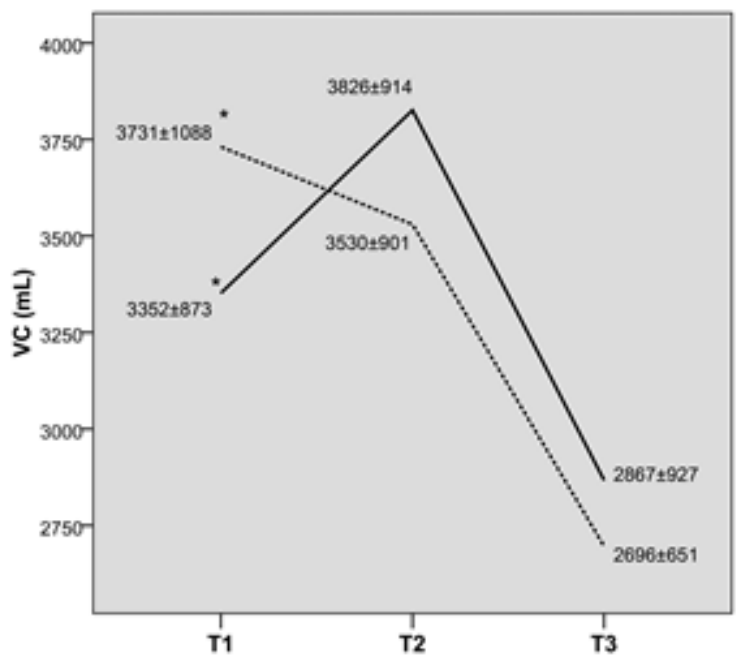

D

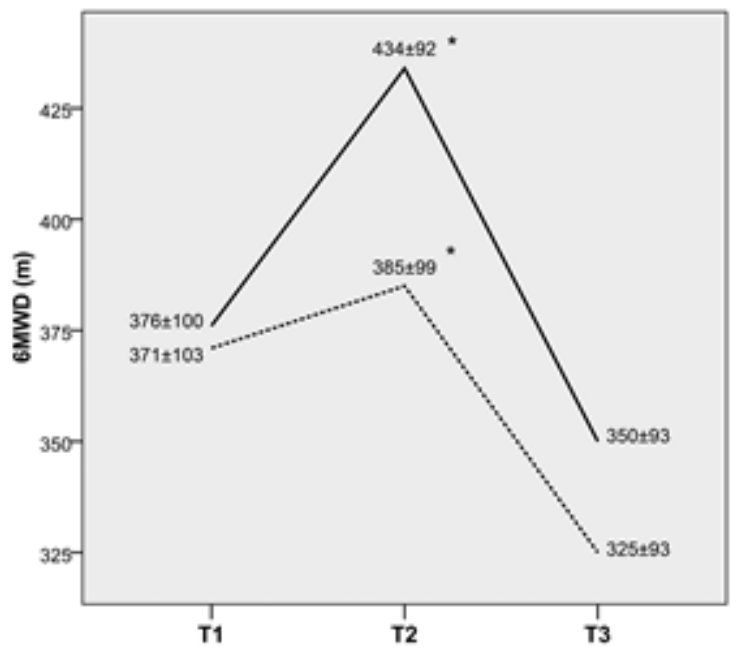

Figure 2. Changes of lung function parameters before and after resection. (A) Change in $\mathrm{FEV}_{1}(\mathrm{~mL})$ before and after resection in the Group A and Group B, [*] p<0.001. (B) Change in VC (mL) before and after resection in the Group A and Group B, [*] $\mathrm{p}=0.055$. (C) Change in $\mathrm{FEF}_{50}$ (black line) and $\mathrm{FEF}_{25}$ (gray line) before and after resection in the Group A and Group B, [*, \#] $\mathrm{p}<0.001,[\dagger, \dagger, \S] \mathrm{p}<0.05$. (D) Change in 6MWD (in meters) before and after lung resection in the Group A and Group B, [*] $<<0.05$. $\mathrm{FEV}_{1}=$ forced expiratory volume in the first second; $\mathrm{VC}=$ vital capacity; $6 \mathrm{MWD}=$ six minute walking distance; $\mathrm{FEF} 50 / 25=$ forced expiratory flow; $\mathrm{T} 1=$ values at admission to hospital; $\mathrm{T} 2=$ values before resection (after physiotherapy); T3=values after surgery. Filled line and dotted line represent Group A and Group B, respectively.

As for IC\% (Fig. 3), a significant difference in mean values was found before lung surgery between groups A and $B(74 \pm 11$ vs $84 \pm 12$, p<0.05), while there wasn't any significant difference between mean values after lung surgery. After physiotherapy in group A, a significant improvement in IC\% was found (T1-T2 $74 \pm 11 \%$ vs $84 \pm 7 \%, \mathrm{p}<0.05)$

A significant drop of IC \% was found after lung surgery in group B, while in group A even a slight increase was recorded (mean T1-T3 differences were $+2 \%$ and $-12 \%$ for groups A and B respectively $(\mathrm{p}<0.05)$ ). 
Differences between patients with different degree of COPD in the Group A, in relation to postoperative lung function loss are presented in Table 4 . After the operation, a clear tendency existed towards smaller FEV ${ }_{1}$ loss in patients with moderate to severe, vs. patients with mild COPD. Similarly, the small airways function was less affected after resection in patients with moderate COPD when compared to patients in whom baseline lung function was better $\left(\mathrm{FEF}_{50}: 11 \%\right.$ vs. $22 \%, \mathrm{p}=0.004, \mathrm{FEF}_{25}$ : $9 \%$ vs. $21 \%$, $\mathrm{p}=0.039$ ).

A strong correlation was registered between the amplitude of $\mathrm{FEV}_{1}$ improvement after physiotherapy and postoperative loss in $\mathrm{FEV}_{1}$ in a way that a better $\mathrm{FEV}_{1}$ improvement was associated with more significant loss in FEV $_{1}$ (Fig. 1B).

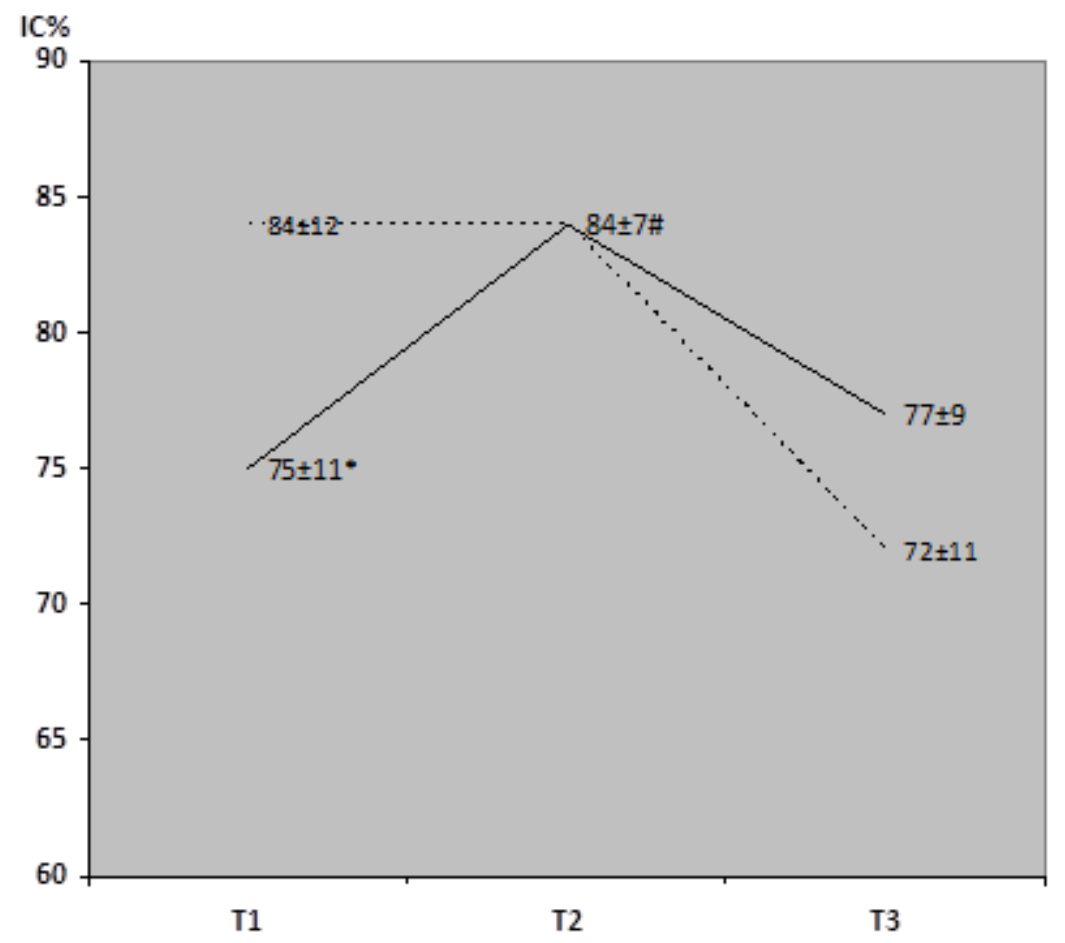

Figure 3. Changes in IC\% before and after lung resection. Group A (full line) and Group B (dotted line), * p $<0.05$ Group A T1 vs Group B T1, \# p <0.05 Group A $\Delta$ (T1-T2). $\mathrm{T} 1=$ values at admission to hospital; $\mathrm{T} 2=$ values before resection (after physiotherapy); $\mathrm{T} 3=$ values after surgery.

Influence of the lung resection to the effort tolerance and symptomatic status

After both types of resection, a significant worsening of the effort tolerance and symptomatic status occurred. The average 6MWT shortening after lobectomy and pneumonectomy was $85 \mathrm{~m}(19 \%, \mathrm{p}<0.001)$ and $87 \mathrm{~m}$ (23\%, p<0.001), respectively (Tables 2 and 3). The average worsening of dyspnea after lobectomy was 0.8 units before $(p<0.001)$ and 1.0 units after the test $(p<0.001)$. The average worsening of the same parameter after pneumonectomy was 0.9 units before $(\mathrm{p}=0.015)$ and 1.0 units after the test $(\mathrm{p}=0.006)$. The obtained results did not differ depending on whether the comparison was made in relation to the status without or with preoperative physiotherapy.

Differences between groups in relation to 6MWT performance between and after the lung resections, are presented in Fig. 2D. Despite the distance at 6MWT was reduced in roughly parallel fashion in both groups, the postoperative performance was significantly better in the Group A. 
Table 4. Postoperative lung function changes depending on severity of COPD at admission in the Group A.

\begin{tabular}{|c|c|c|c|c|c|}
\hline & & $\begin{array}{l}\mathrm{FEV}_{1}<50 \% \\
\operatorname{mean}[95 \% \mathrm{CI}] \\
(\mathrm{n}=7)\end{array}$ & $\begin{array}{l}50 \% \leq \mathrm{FEV}_{1}<80 \% \\
\text { mean }[95 \% \mathrm{CI}] \\
(\mathrm{n}=39)\end{array}$ & $\begin{array}{l}\mathrm{FEV}_{1} \geq 80 \% \\
\text { mean }[95 \% \mathrm{CI}] \\
(\mathrm{n}=10)\end{array}$ & p-value \\
\hline$\Delta[\mathbf{T} 2-\mathrm{T} 1]$ & $\mathrm{FEV}_{1}(\mathrm{~mL})$ & $427[27,827]$ & $328[242,414]$ & $235[74,396]$ & 0.631 \\
\hline & $\mathrm{FEV}_{1} \%$ pred. & $40[-4,86]$ & $18[14,22]$ & $9[3,16]$ & 0.107 \\
\hline & $\mathrm{FEF}_{50}(\%)$ & $7[-14,27]$ & $3[0,6]$ & $3[1,6]$ & 0.857 \\
\hline & $\mathrm{FEF}_{25}(\%)$ & $2[-21,24]$ & $4[1,7]$ & $-4[-15,6]$ & 0.220 \\
\hline$\Delta[\mathrm{T} 2-\mathrm{T3}]$ & $\mathrm{FEV}_{1}(\mathrm{~mL})$ & $442[180,703]$ & $580[491,667]$ & $749[511,987]$ & 0.152 \\
\hline & $\mathrm{FEV}_{1} \%$ pred. & $25[14,36]$ & $26[22,30]$ & $27[19,34]$ & 0.980 \\
\hline & $\mathrm{FEF}_{50}(\%)$ & $9[3,16]$ & $11[7,15]^{*}$ & $22[16,28]^{*}$ & 0.004 \\
\hline & $\mathrm{FEF}_{25}(\%)$ & $6[2,11]$ & $9[5,14] \dagger$ & $21[12,31] \dagger$ & 0.039 \\
\hline
\end{tabular}

COPD=chronic obstructive pulmonary disease; $\Delta=$ difference between two measured values; $\mathrm{T} 1=$ values before preoperative physiotherapy; $\mathrm{T} 2=\mathrm{values}$ after preoperative physiotherapy; $\mathrm{T} 3=$ =values after lung resection; $\mathrm{FEV}_{1}=$ forced expiratory volume in the first second; $\mathrm{FEF}=$ forced expiratory flow. ${ }^{*} p<0.001$, for subgroups of mild vs. moderate COPD patients.

$+\mathrm{p}=0.012$, for subgroups of mild vs. moderate COPD patients.

\section{DISCUSSION}

The exact contribution of physiotherapy to the treatment outcome in patients with lung carcinoma is still not well defined. Furthermore, previously obtained results were not always validated by the comparison with postoperative lung function [14]. However, rare studies of this type confirmed the beneficial effect of physiotherapy in a way that actual postoperative $\mathrm{FEV}_{1}$ and $\mathrm{VC}$ values were significantly higher than predicted, both after lobectomy and pneumonectomy [15].

In our study, a difference in the effect of preoperative physiotherapy was registered depending on the extent of a resection. We have demonstrated that only in a patients requiring a lobectomy, there was a significant improvement of the lung function. Such findings might be explained by the limited number of patients in the pneumonectomy group. It was stated previously that for the patients with a stage III-IV disease, physiotherapy did not achieve significant lung function improvement [16].

Although in the present study the lung function improvement was evident after preoperative physiotherapy, it should be pointed out that the improvement in $\mathrm{FEV}_{1}, \mathrm{FEF}_{50}$ and $\mathrm{FEF}_{25}$ was similar independently of severity of COPD, if stratified as $\mathrm{FEV}_{1} \%$ $<50 \%, 50-80 \%$ and $>80 \%$.

Data on effects of preoperative physiotherapy on improvement in lung volumes and flows are conflicting. While some authors didn't find any significant improvement in spirometric values after preoperative physiotherapy $[17,18]$, others found significant increase not only in FVC and $\mathrm{FEV}_{1}[19,20]$, but also in diffusion capacity and other parameters (21). One can only speculate that differences in obtained data reflect differences in study designs, number of included patients and physiotherapy protocols.

The postoperative loss of ventilatory function in the analyzed group followed the well-known pattern after both types of resection [22-24], but with evidently smaller loss in the postoperative function of small airways compared with $\mathrm{FEV}_{1}$ and VC. Comparison of the postoperative small airways function between evaluated study groups confirms the significance of preoperative $\mathrm{FEF}_{50}$ and $\mathrm{FEF}_{25}$, despite the similar trend of loss of their values. Patients with initially better small airways function retain their better function as well after resection. Such observations point out that the aim of preoperative physiotherapy is not only to improve $\mathrm{FEV}_{1}$ and Tiffeneau index, but also to achieve a stable function of the small airways, i.e. to maintain adequate flow at low lung volumes. This is in line with our previous report on 35 COPD patients in whom $18 \%$ and $25.6 \%$ improvement in $\mathrm{FEF}_{50}$ was registered after lobectomy, compared with slight decrease of these values in the control group [25]. The tendency of smaller FEV $\mathrm{Fl}_{1}$ loss in patients with moderate and severe COPD, compared with patients with better preserved lung function, as registered in our study, additionally supports similar results published in recent years, demonstrating that such a finding does not always exist only due to lung volume reduction effect [26,27]. This is due to the fact that in the analyzed group A in 6 (22\%) patients, the mean improvement in $\mathrm{FEV}_{1}$ after lobectomy was registered (ranging 10\%-35\%), despite the absence of major emphysema in the resected lobes.

Of even greater practical significance is our finding that a better $\mathrm{FEV}_{1}$ improvement after physiotherapy was 
associated with greater postoperative loss in $\mathrm{FEV}_{1}$. Such a finding could put into question the overall benefit of physiotherapy. However, comparison of postoperative $\mathrm{FEV}_{1}, \mathrm{VC}$ and small airways function loss between the evaluated groups demonstrated that, although the similar degree of FEV 1 and VC decrease cannot be avoided, the more consistent small airways function persists throughout the early postoperative period, thus justifying such a concept.

As most complications occur just in the early postoperative period, the overestimate of up to $30 \%$ for $\mathrm{FEV}_{1}$ on first postoperative day, further supports the role of physiotherapy [28]. Given the aforementioned major fluctuations in $\mathrm{FEV}_{1}$ depending on severity of COPD, our confirmation of the small airways function consistency seems to be a significant factor in reducing the postoperative complications rate.

There is still no consensus whether prediction of postoperative $\mathrm{FEV}_{1}$ should be calculated in relation to the worst or best preoperative values (as in the current study) and whether smoking cessation before surgery makes sense. In the analyzed group, smoking cessation was obligatory. Tobacco smoke and accompanying vagal denervation stimulate retention of secretion and desaturation. Impaired lung vascularization in COPD patients favors the prolonged air leak [29]. It was also suggested that smoking cessation may decrease postoperative inflammation and in the long-term may decrease the risk of recurrence [30].

Inspiratory capacity is used as an indirect estimation of functional residual capacity, and its reduction can be an indicator of presence of static or dynamic lung hyperinflation [31], which is responsible for marked dyspnea and exercise limitation in patients with COPD [32,33]. Furthermore, preoperative IC\% is strong predictor for the development of perioperative complications after lung resection surgery, which is independent of $\mathrm{FEV}_{1}$ [34]. So, a significant improvement in $\mathrm{IC} \%$ in patients who underwent preoperative physiotherapy clearly indicates reduction of pulmonary hyperinflation, and, therefore, reduced risk for perioperative pulmonary complications. This is also shown in patients with COPD who underwent coronary bypass graft surgery [35].

A significant reduction in all lung volumes is a consequence of any type of lung surgery. Therefore, we observed an expected significant drop in IC in both group of patients. But, net loss in IC\% was observed only in patients who didn't underwent physiotherapy, which suggests that preoperative improvement in IC\% due to physiotherapy prevents its significant drop after lung resection. Prevention of IC\% loss probably reduces the risk for postoperative dyspnea and pulmonary complications.
The present study demonstrated significant improvement in 6MWD that correlated with improvement of ventilatory function, thus confirming a role of physiotherapy in the decrease of the overall operative risk. Comparisons that were related to 6MWD between evaluated groups of patients from our study, apart from demonstrating the significant increase of the walking distance after physiotherapy, also confirmed that in those patients, the postoperative distance remained longer as well. Such a finding additionally supports the role of physiotherapy. Furthermore, significant improvement in the effort tolerance after physiotherapy may not be accompanied by similar improvement of the ventilatory function, as was recently demonstrated [17]. Similarly, preoperative improvement of the effort tolerance does not always correlate with the same effect on the ventilatory function [18].

Several prospective randomized studies pointed out that the water seal policy after pulmonary resections is also able to shorten the duration of air leak as well todecreased the time for chest tubes to remain in place, with the exception of large leak (> E4) [36]. However, it was recently demonstrated that pleural suction leads to a large decrease of differential pleural pressure after upper lobectomy, mainly due to a less negative inspiratory pressure after applying of suction [37].

The question whether the site of lobectomy has some impact to postoperative ventilatory function is still controversial [38,39]. The present study did not demonstrate a significant difference in the loss of $\mathrm{FEV}_{1}$ depending on site of lobectomy, but only the greater decrease for the small airways' function after upper lobectomy ( $\mathrm{FEF}_{50}: 16 \%$ vs $\left.10 \%\right)$.

Our study has several limitations. First of all, the patients were not properly randomized to the groups according to well-defined criteria. Instead, they were consecutively assigned to the groups. Our explanation is that there aren't any well-defined criteria for implementation of physiotherapy in patients with COPD selected for lung resection surgery and that physiotherapy is indicated for all such patients. Next, due to technical reasons, we haven't directly measured static lung volumes (namely TLC, FRC and RV), but instead IC\% was used as an estimation. Finally, we didn't take into account an influence of other factors on incidence of pulmonary complications after surgery.

Lack of significant effect of preoperative physiotherapy on most pulmonary function parameters after lung resection, which was shown in our study, was rather disappointing. Nevertheless, positive effects of preoperative physiotherapy on preservation of static lung volumes and on increase of exercise tolerance after surgery lead us to believe in importance of preoperative physiotherapy in COPD patients selected for lung 
resection. It is quite clear that further studies better designed and with larger number of patients are needed to clarify this dilemma.

\section{References}

[1] Brunelli A, Charloux A, Bolliger CT, Rocco G, Sculier JP, Varela G, Licker M, Ferguson MK, Faivre-Finn C, Huber RM, Clini EM, Win T, De Ruysscher D, Goldman L; European Respiratory Society and European Society of Thoracic Surgeons joint task force on fitness for radical therapy (2009). ERS-ESTS clinical guidelines for evaluating fitness for radical treatment (surgery and chemoradiotherapy) in patients with lung cancer. Eur Respir J, 34:17-41.

[2] Ohno Y, Koyama H, Takenaka D, Nogami M, Kotani Y, Nishimura Y, Yoshimura M, Yoshikawa T, Sugimura K (2007). Coregistered ventilation and perfusion SPECT using krypton- $81 \mathrm{~m}$ and Tc-99mlabeled macroaggregated albumin with multislice $\mathrm{CT}$ utility for prediction of postoperative lung function in non-small cell lung cancer patients. Acad Radiol, 14:830-8.

[3] Yoshimoto K, Nomori H, Mori T, Kobayashi H, Ohba Y, Shibata H, Shiraishi S, Kobayashi T (2009). Prediction of pulmonary function after lung lobectomy by subsegments counting, computed tomography, single photon emission computed tomography and computed tomography: a comparative study. Eur J Cardiothorac Surg, 35:408-13.

[4] Sullivan V, Tran T, Holmstrom A, Kuskowski M, Koh P, Rubins JB, Kelly RF (2005).Advanced age does not exclude lobectomy for non-small cell lung carcinoma. Chest, 128:2671-6.

[5] Sawada S, Komori E, Nogami N, Bessho A, Segawa Y, Shinkai T, Nakata M, Yamashita M (2005). Advanced age is not correlated with either short-term or long-term postoperative results in lung cancer patients in good clinical condition. Chest, 128:1557-63.

[6] Wang JS, Abboud RT, Evans KG, Finley RJ, Graham BL (2000). Role of CO diffusing capacity during exercise in the preoperative evaluation for lung resection. Am J Respir Crit Care Med, 162:1435-44.

[7] Mujovic N, Mujovic N, Subotic D, Marinkovic M, Milovanovic A, Stojsic J, Zugic V, Grajic M, Nikolic D (2014).Preoperative Pulmonary Rehabilitation in Patients with Non-small Cell Lung Cancer and Chronic Obstructive Pulmonary Disease. Arch Med Sci, 10:6875.

[8] Pauwels RA, Buist AS, Calverley PM, Jenkina CR, Hurd SS, GOLD Scientific Committee (2001). Global strategy for diagnosis, management and prevention of chronic obstructive pulmonary disease. NHLBI/WHO Global Initiative for Chronic Obstructive Lung Disease (GOLD) workshops summary. Am J Respir Crit Care Med, 163:1256-76.

[9] Miller MR, Hankinson J, Brusasco V, Burgos F, Casaburi R, Coates A, Crapo R, Enright P, van der Grinten CP, Gustafsson P, Jensen R, Johnson DC,
MacIntyre N, McKay R, Navajas D, Pedersen OF, Pellegrino R, Viegi G, Wanger J; ATS/ERS Task Force (2005). Standardisation of spirometry. Eur Respir J, 26:319-38.

[10] Quanjer PH, Tammeling GJ, Cotes JE, Pedersen OF, Peslin R, Yernault J-C (1993). Lung volume and forced ventilatory flows. Report Working Party Standardization of Lung Function Tests, European Community for Steel and Coal. Official Statement of the European RespiratorySociety. Eur Respir J Suppl, 16:5-40.

[11] De Leyn P, Lardinois D, Van Schil PE, Rami-Porta R, Passlick B, Zielinski M, Waller DA, Lerut T, Weder W (2007). ESTS guidelines for preoperative lymph node staging for non-small cell lung cancer. Eur J Cardiothorac Surg, 32:1-8.

[12] ATS Committee on Proficiency Standards for Clinical Pulmonary Function Laboratories (2002). ATS statement: Guidelines for the Six-Minute Walk Test. Am J Respir Crit Care Med, 166:111-7.

[13] Mador MJ, Rodis A, Magalang UJ (1995). Reproductibility of Borg scale measurements of dyspnea during exercise in patients with COPD. Chest, 107;1590-7.

[14] Cesario A, Ferri L, Galetta D, Cardaci V, Biscione G, Pasqua F, Piraino A, Bonassi S, Russo P, Sterzi S, Margaritora S, Granone P (2007). Pre-operative pulmonary rehabilitation and surgery for lung cancer. Lung Cancer, 57:118-9.

[15] Weiner P, Man A, Weiner M, Rabner M, Waizman J, Magadle R, Zamir D, Greiff Y (1997). The effect of incentive spirometry and inspiratory muscle training on pulmonary function after lung resection. J Thorac Cardiovasc Surg, 113:552-7.

[16] Ozalevli S, Ilgin D, Karaali HK, Bulac S, Akkoclu A (2010). The effect of in-patient chest physiotherapy in lung cancer patients. Support Care Cancer, 18:351-8.

[17] Bobbio A, Chetta A, Ampollini L, Primomo GL, Internullo E, Carbognani P, Rusca M, Olivieri D (2008). Preoperative pulmonary rehabilitation in patients undergoing lung resection for non-small cell lung cancer. Eur J Cardiothorac Surg, 33:95-8.

[18] Jones LW, Peddle CJ, Eves ND, Haykowsky MJ, Courneya KS, Mackey JR, Joy AA, Kumar V, Winton TW, Reiman T (2007). Effects of presurgical exercise training on cardiorespiratory fitness among patients undergoing thoracic surgery for malignant lung lesions. Cancer, 110:590-8.

[19] Liu W, Pan YL, Gao CX, Shang Z, Ning LJ, Liu X (2013). Breathing exercises improve post-operative pulmonary function and quality of life in patients with lung cancer: A meta-analysis. Exp Ther Med, 5:1194200.

[20] Divisi D, Di Francesco C, Di Leonardo G, Crisci R (2013). Preoperative pulmonary rehabilitation in patients with lung cancer and chronic obstructive pulmonary disease. Eur J Cardiothorac Surg, 43:293-6.

[21] Pehlivan E, Turna A, Gurses A, Gurses HN (2011). The effects of preoperative short-term intense physical therapy in lung cancer patients: a randomized 
controlled trial. Ann Thorac Cardiovasc Surg, 17:4618.

[22] British Thoracic Society; Society of Cardiothoracic Surgeons of Great Britain and Ireland Working Party (2001). BTS guidelines: guidelines on the selection of patients with lung cancer for surgery. Thorax, 56:89108.

[23] Colice GL, Shafazand S, Griffin JP, Keenan R, Bolliger CT; American College of Chest Physicians (2007). Physiologic evaluation of the patient with lung cancer being considered for resectional surgery: ACCP evidenced-based clinical practice guidelines $\left(2^{\text {nd }}\right.$ edition). Chest, 132(Suppl 3):161S-177S.

[24] Korst RJ, Ginsberg RJ, Ailawadi M, Bains MS, Downey RJ Jr, Rusch VW, Stover D (1998).Lobectomy improves ventilatory function in selected patients with severe COPD. Ann Thorac Surg, 66:898-902.

[25] Subotić D, Mandarić D, Eminović T, Gajic MM, Mujovic NM, Atanasijadis ND, Dzeletovic PP, Andric LD, Bulajic BM, Dimitrijevic ID, Sobic DP (2007).Influence of chronic obstructive pulmonary disease on postoperative lung function and complications in patients undergoing operations for primary non-small cell lung cancer. J Thorac Cardiovasc Surg, 134:1293-8.

[26] Baldi S, Ruffini E, Harari S, Roviaro GC, Nosotti M, Bellaviti N, Venuta F, Diso D, Rea F, Schiraldi C, Durigato A, Pavanello M, Carretta A, Zannini P (2005).Does lobectomy for lung cancer in patients with chronic obstructive pulmonary disease affect lung function? A multicenter national study. J Thorac Cardiovasc Surg, 130:1616-22.

[27] Santambrogio L, Nosotti M, Baisi A, Ronzoni G, Bellaviti N, Rosso L (2001). Pulmonary lobectomy for lung cancer: a prospective study to compare patients with forced expiratory volume in $1 \mathrm{~s}$ more or less than 80\% of predicted. Eur J Cardiothorac Surg, 20:684-7.

[28] Varela G, Brunelli A, Rocco G, Marasco R, Jiménez MF, Sciarra V, Aranda JL, Gatani T (2006). Predicted versus observed FEV1 in the immediate postoperative period after pulmonary lobectomy. Eur J Cardiothorac Surg, 2006; 30:644-8.

[29] Favier R, Kepenkian G, Desplanches D, Flandrois R (1982). Effects of chronic lung denervation on breathing pattern and respiratory gas exchange during hypoxia, hypercapnia and exercise. Respir Physiol, 47:107-19.

[30] Robles AM, Shure D (2004). Optimization of lung function before pulmonary resection: pulmonologists' perspectives. Thorac Surg Clin, 14:295-304.

[31] Tantucci C, Duguet A, Similowki T, Zelter M, Derenne $\mathrm{J}-\mathrm{Ph}$, Milic-Emili J (1998). Effect of salbutamol on dynamic hyperinflation in chronic obstructive pulmonary disease patients. Eur Rspir J, 12:799-804.

[32] O'Donnell DE (1994). Breathlessness in patients with chronic airflow limitation. Mechanisms and management. Chest, 106:904-12.

[33] Diaz O, Villafranca C, Ghezzo H, Borzone G, Leiva A, Milic-Emil J, Lisboa C (2000). Role of inspiratory capacity on exercise tolerance in COPD patients with and without expiratory flow limitation at rest. Eur Respir J, 16:269-75.

[34] Matsuo M, Hashimoto N, Usami N, Imaizumi K, Wakai K, Kawabe T, Yokoi K, Hasegawa Y (2012). Inspiratory capacity as a preoperative assessment of patients undergoing thoracic surgery. Interact Cardiovasc Thorac Surg, 14:560-4.

[35] Rajendran AJ, Pandurangi UM, Murali R, Gomathi S, Vijayan VK, Cherian KM (1998). Pre-operative pulmonary rehabilitation for patients of chronic obstructive pulmonary disease undergoing coronary bypass graft surgery. Indian Heart J, 50:531-4.

[36] Cerfolio RJ, Bryant AS, Singh S, Bass CS, Bartolucci AA (2005). The management of chest tubes in patients with a pneumothorax and an air leak after pulmonary resection. Chest, 128:816-20.

[37] Varela G, Brunelli A, Jiménez MF, Di Nunzio L, Novoa N, Aranda JL, Sabbatini A (2010). Chest drainage suction decreases differential pleural pressure after upper lobectomy and has no effect after lower lobectomy. Eur J Cardiothorac Surg, 37:531-4.

[38] Sekine Y, Iwata T, Chiyo M, Yasufuku K, Motohashi S, Yoshida S, Suzuki M, Iizasa T, Saitoh Y, Fujisawa T (2003). Minimal alteration of pulmonary function after lobectomy in lung cancer patients with chronic obstructive pulmonary disease. Ann Thorac Surg, 76:356-62.

[39] Beccaria M, Corsico A, Fulgoni P, Zoia MC, Casali L, Orlandoni G, Cerveri I (2001). Lung cancer resection: the prediction of postsurgical outcomes should include long-term functional results. Chest, 120:37-42. 